\title{
Analysis of Indigenous Food Items of Monpa Tribal Community in Tawang District of Arunachal Pradesh, India
}

\author{
Nitin Kumar Pandey ${ }^{1 *}$, D.S. Chhonkar ${ }^{1}$, Dhiraj K. Singh ${ }^{2}$ and Sonam Tsering Khumu ${ }^{1}$ \\ ${ }^{1}$ Krishi Vigyan Kendra, Tawang, Arunachal Pradesh, India \\ ${ }^{2}$ ICAR-Research Complex for Eastern Region, Patna, Bihar, India \\ *Corresponding author
}

\section{A B S T R A C T}

\begin{tabular}{|c|c|}
\hline $\mathrm{Ke}$ & \multirow{7}{*}{$\begin{array}{l}\text { There had been cumulative learning from generation to generation among the tribal } \\
\text { societies living in close vicinity of the nature. They process and prepare several type of } \\
\text { peculiar food and beverage items which are location specific and made with the help of } \\
\text { traditional knowledge. Keeping these issues in mind, current study was conducted among } \\
\text { the Monpa tribe of Tawang district of Arunachal Pradesh. The sample size of the study } \\
\text { comprised of } 120 \text { respondents from this tribe. Personal interview method with a pre-tested } \\
\text { structured schedule and focused group discussion were used for data collection. Results } \\
\text { revealed that Monpa tribe had mastered the method of preparation of a range of food items } \\
\text { and beverages. These food items include Thukpa, Momos, Khura, Zan, Puta, Khazi, Bresi, } \\
\text { Khapse, Chhurpi etc which are prepared with the help of crops like rice, wheat, maize, } \\
\text { barley, finger millet, buckwheat, vegetables and yak meat as well as milk. The beverages } \\
\text { locally known as Sing-chang, Baang-chang, Aarak, Marchang, Monpa tea etc were } \\
\text { prepared from fermentation, distillation and brewing of foodgrains. These kinds of cultural } \\
\text { diversity needs to be preserved in India to have a distinctive feature which can be very } \\
\text { good potential for tourism industry. }\end{array}$} \\
\hline & \\
\hline & \\
\hline & \\
\hline & \\
\hline & \\
\hline & \\
\hline
\end{tabular}

\section{Introduction}

Human is a social animal. Human behavior varied from place to place and sometimes too complex to analyze and understand. Most of us behave in a particular manner because of our habits, ideology or predominant thought at the moment. Tribal communities have close relation with the environment where they live. They know how to identify and observe their food and biological responses to the particular area. Such knowledge can be acquired from the old man or head of the family/ societies. Arunachal Pradesh is a hilly state of Northeastern India where shifting cultivation is a major practice in agriculture.
The state is very rich in traditional food and beverages and tribal communities process agricultural produce using various methods (Singh and Sureja, 2005). The Monpa tribe of Arunachal Pradesh inhabits at higher altitude ranging between 3,500 and 22,500 feet from mean sea level in Tawang District. The Monpas have generally three meals in a day. The first meal taken in the early morning before going out to the fields, forest or other business. While going to the forest fields, cooked items to be taken for lunch in a bamboo basket. Third meal is taken at home in the evening. The main food of Monpa is 
rice and millets. Although men and women have equal options and opportunities to use and conserve the biodiversity for sustaining their livelihoods under challenges of climate change and socioeconomic inequalities, they like duck meat, chicken and fish (Singh, R.K et al., 2013). Monpas are traditionally dependent on nature and natural products for food and medicines. They have rich knowledge about processing of food, medicine and edible plants which is generally used for welfare of the societies.

Tawang district having varied physiographic and agro-climatic conditions, the agricultural practices and prospects of this area differs in some extent from other districts of the state. Diversity of this district is congenial for commercial cultivation of both tropical and temperate fruits, Orchid species, Potato, Ginger, Species, Medicinal and Aromatic plants etc. The economy of Monpas is basically agrarian and rural based. They practice both permanent and shifting (Jhum) cultivation. Maize, paddy, millets, wheat, buckwheat, barley, soyabean, chilli, frenchbean, cabbage and potato are major crops grown by this tribe (Bareh, 2001). Biocultural dimensions of biodiversity memorized and traditional mechanisms adapted by elderly women transfer their plant and cultural knowledge from one to another generation (Singh et al., 2013).

With passage of time, preparation and use of traditional foods are decreasing against modern foods. Different type of knowledge about plants, indigenous foods, meditational plant, fermented product and their uses in food nutritional security is available among elderly people of the community. The loss of traditional culture and ethno medicinal related aspect of the important traditional food and beverage adopted by Monpa tribe has been a cause of concern in recent times. Keeping all this in mind, the present study was conducted on preparation of an inventory of culturally and nutritionally important foods, beverages among Monpa tribes of the district.

\section{Materials and Methods}

The state of Arunachal Pradesh, at the extreme North East of India, occupies an area of about 83, 743 sq. kilometer. It is bounded on north by Tibet and China, on the west by Bhutan on the south by the state of Assam and on the east by Burma and Nagaland. There are 21 districts in the state. The state is basically a tribal state. Tawang is a land of Monpa tribes, is a small district blessed with breath- taking natural beauty. This is situated is the north western extremity of the state of Arunachal Pradesh. It is the birth place of this Holiness the sixth Dalai Lama and home to world famous Gaden Namgyal Lhatse, Popularly Known as Tawang Monastery, the largest Monastery of India and perhaps the second largest in Asia (Abhisekh, 2015). As per census of 2011, there are a total of 268 villages in the district. The present study was conducted in purposively selected Tawang district having 90\% Monpas of its total population. Four villages each from two blocks- Tawang and Kitpi of the district were selected randomly and from each selected village (Changbu, Changprong, Shakti, Ghispu, Teli, Soma, Yousum, Khirmu) 15 members were randomly selected as sample of respondent. The sample of the study, thus comprised of 120 members of Monpa tribe. For better understanding of valuable information help of local officers' viz. Agriculture field assistant (AFA), Gaon Burah and ASM were taken. A list of the members having traditional knowledge about indigenous food and beverage was prepared. An open ended interview schedule was developed to collect the data. The data were collected through personal interview from the respondents and focused group discussion. The participatory observation was major tool 
to record the method of preparation of traditional food, medicine and beverages made by different crops. The collected information was analyzed with suitable techniques.

\section{Results and Discussion}

\section{Identification of crops used for preparation of traditional food by the Monpa tribes}

It was observed that the Monpa tribes prepare boiled, fermented and processed food and beverage which were nutritionally and medicinally rich for the communities. They use various cereals, vegetables and other minor crops in preparation of their traditional food. Millets are the staple food of these tribes. The following crops in table 1 have been identified during the study which is used for preparation of traditional food.

\section{Food items and their preparation}

The Monpas are quite fond of specific spicy food. Therefore, chillies are used extensively in their preparations. A very popular side dish, which every typical household prepares as an accompaniment is called chamin (local chutney), made by the grinding of chillies with fermented cheese. Fermented cheese is also a key ingredient in almost all of their traditional preparation and is found in every household. They also use fermented soya beans (Glycine max Merrill) called grebchurba as a flavoring agent.

The Monpa are non-vegetarians and prefer beef, pork, yak, mutton, chicken and fish over vegetables. Beef and yak meat is cut into strips and dried during winter months to be consumed later (Maiti, 2013). This study was conducted among sampled households and different types of food items prepared by Monpas were identified (Fig. 1). The details of these items are given below.

\section{Thukpa}

It is among most popular and common dishes in Tawang. Thukpa is basically a noodle soup mixed with meat, chillies, etc. Another kind of thukpa is dheb thupka in which noodles are replaced by rice. Thukpa made of maize and beans is called ashumthukpa and made by yak meat or chicken is known as shathukpa.

\section{Momos}

Momos are very popular in various parts of the country. These are made by stuffing a mixture of meat and onion in dough. They are then steamed for about half an hour in a threetiered perforated utensil placed above another utensil containing water for soup at the bottom.

They are then served with soup and hot chamin. Non-veg momo is made from maida and pork, yak meat, packed fish, chicken and mutton and veg-momo is prepared by the use of maida and leafy vegetables (cabbage, man patta, onion leaf).

\section{Khura}

A Monpa pancake made of buckwheat flour which is usually eaten with tea or vegetable curry. It is prepared by mixing sugar, water and buckwheat flour in haying (local bowl). After wards the mixture is toasted in a langya (pan).

\section{Zan}

This staple food is prepared by adding millets or another flour to boiling water in haying. Mixture is stirred with a flat wooden spatula till it becomes stiff.

It is consumed with vegetables, meat or chamin along with the addition of fermented cheese or soyabeans as condiment. 
Table.1 Use of traditional crops in ethnic foods

\begin{tabular}{|c|c|c|c|c|c|}
\hline Species & $\begin{array}{l}\text { Local } \\
\text { Name }\end{array}$ & Botanical Name & $\begin{array}{l}\text { Part Use in } \\
\text { food }\end{array}$ & $\begin{array}{l}\text { Season of } \\
\text { Availability }\end{array}$ & Conservation mode \\
\hline Barley & Nai & Hordeum vulgare & Grain & May - June & $\begin{array}{l}\text { Shifting land and home } \\
\text { garden }\end{array}$ \\
\hline $\begin{array}{l}\text { Finger } \\
\text { millets }\end{array}$ & Comp & $\begin{array}{l}\text { Eleusine } \\
\text { coracana }\end{array}$ & Grain & November & Shifting land \\
\hline Wheat & Ko, Nass & Triticum astivam & Grain & May - June & $\begin{array}{l}\text { Shifting land and home } \\
\text { garden }\end{array}$ \\
\hline $\begin{array}{l}\text { Buck } \\
\text { wheat }\end{array}$ & Brame & $\begin{array}{l}\text { Fagopyrum } \\
\text { esculentum } \\
\text { Moench }\end{array}$ & $\begin{array}{l}\text { Immature } \\
\text { grain use for } \\
\text { Tem(Vegeta } \\
\text { ble), Mature } \\
\text { grain use for } \\
\text { Phe (Atta) }\end{array}$ & April- May & $\begin{array}{l}\text { Shifting land, home } \\
\text { garden and community } \\
\text { forest }\end{array}$ \\
\hline Rice & Debh, $\mathrm{Nu}$ & Oryza sativa & Grain & $\begin{array}{l}\text { October } \\
\text { November }\end{array}$ & Shifting land \\
\hline Maize & Ashom & Zea Mays & $\begin{array}{l}\text { Immature } \\
\text { and mature } \\
\text { grain }\end{array}$ & $\begin{array}{l}\text { July to } \\
\text { October }\end{array}$ & $\begin{array}{l}\text { Shifting land and home } \\
\text { garden }\end{array}$ \\
\hline Cabbage & $\begin{array}{l}\text { Rupong, } \\
\text { Pongru }\end{array}$ & $\begin{array}{l}\text { Brassica oleracea } \\
\text { var.capitata }\end{array}$ & Leaf & Round year & $\begin{array}{l}\text { Shifting land and home } \\
\text { garden }\end{array}$ \\
\hline $\begin{array}{l}\text { Local } \\
\text { Spanich }\end{array}$ & Patse & Spinaciao leracia & Leaf & $\begin{array}{l}\text { April to } \\
\text { October }\end{array}$ & $\begin{array}{l}\text { Domesticated in home } \\
\text { garden }\end{array}$ \\
\hline Radish & Ker & Raphanus sativa & root & Round year & $\begin{array}{l}\text { Domesticated in home } \\
\text { garden }\end{array}$ \\
\hline $\begin{array}{l}\text { Bitter } \\
\text { gourd }\end{array}$ & $\begin{array}{l}\text { Khau } \\
\text { Bando, Ru, } \\
\text { Kho Kairy }\end{array}$ & $\begin{array}{l}\text { Momordica } \\
\text { charantia }\end{array}$ & Fruit & $\begin{array}{l}\text { July to } \\
\text { October }\end{array}$ & $\begin{array}{l}\text { Shifting land and home } \\
\text { garden }\end{array}$ \\
\hline Pumpkin & Brumsa & $\begin{array}{l}\text { Cucurbita } \\
\text { moschata }\end{array}$ & $\begin{array}{l}\text { Fruit, Tender } \\
\text { leaf }\end{array}$ & $\begin{array}{l}\text { July to } \\
\text { September }\end{array}$ & $\begin{array}{l}\text { Shifting land and home } \\
\text { garden }\end{array}$ \\
\hline Onion & Tshong & Allium cepa & Leaf, Bulb & January & $\begin{array}{l}\text { Shifting land and home } \\
\text { garden }\end{array}$ \\
\hline Garlic & chhet & Allium sativam & Leaf, Bulb & August & $\begin{array}{l}\text { Shifting land and home } \\
\text { garden }\end{array}$ \\
\hline Lettuce & Notch Ru & Lactuca sativa & Leaf & $\begin{array}{l}\text { April to } \\
\text { October }\end{array}$ & $\begin{array}{l}\text { Shifting land and home } \\
\text { garden }\end{array}$ \\
\hline Layi Patta & Petsa Ru & Brasicca spp. & Leaf & Whole year & $\begin{array}{l}\text { Domesticated in home } \\
\text { garden }\end{array}$ \\
\hline $\begin{array}{l}\text { Local } \\
\text { chillies }\end{array}$ & Solu & $\begin{array}{l}\text { Capsicum } \\
\text { frutescence }\end{array}$ & fruit & $\begin{array}{l}\text { July to } \\
\text { September }\end{array}$ & $\begin{array}{l}\text { Domesticated in home } \\
\text { garden }\end{array}$ \\
\hline Man patta & Man & Allium spp. & Leaf & April to July & $\begin{array}{l}\text { Shifting land, home } \\
\text { garden and community } \\
\text { forest }\end{array}$ \\
\hline $\begin{array}{l}\text { Local } \\
\text { Mushroom }\end{array}$ & Moo & Agaricus Spp. & Whole plant & April to July & Community forest \\
\hline Soya bean & Kya grap & $\begin{array}{l}\text { Glycine } \\
\text { Merrill }\end{array}$ & Grain & October & Shifting land \\
\hline
\end{tabular}


Table.2 Preparation and form of ethnic foods

\begin{tabular}{|l|l|l|}
\hline Name of Ethnic food & Form of food & Preparation time \\
\hline Thukpa & Soup noodle & Mainly serve in the dinner \\
\hline Momos & Steamed & Any special occasion \\
\hline Khura & Roasted & Any time \\
\hline Zan & Boiled & Special occasion \\
\hline Puta & Boiled & Religious occasion \\
\hline Gypa Khazi & steamed & Any time \\
\hline Tsizing Kyola & Boiled & Whole year \\
\hline Bresi & Fried & Religious occasion, Festival \\
\hline Khazi & Steamed & Any time \\
\hline Khapse & Fried & Losar (New Year) \\
\hline Chhurpi & Fermented & Round the year \\
\hline Soyabean chhurpi & Fermented & Round the year \\
\hline Yak Meat & Boil, Fry, Snakes, Dry, and Roasted & As per availability \\
\hline Yak Fat & Churning & Whole year \\
\hline
\end{tabular}

Fig.1 Pictorial depiction of Indigenous food items of Monpa tribe in Tawang

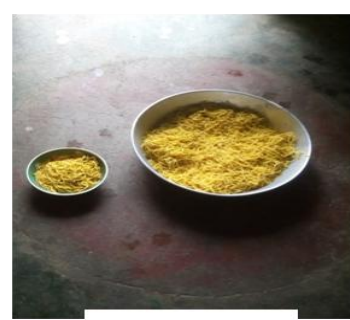

Thukpa

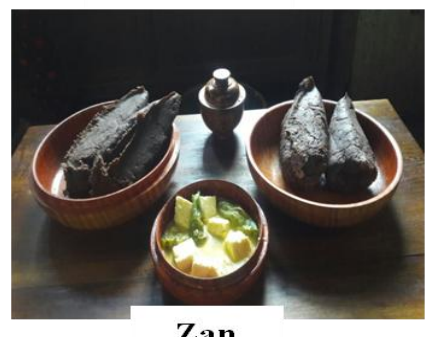

Zan

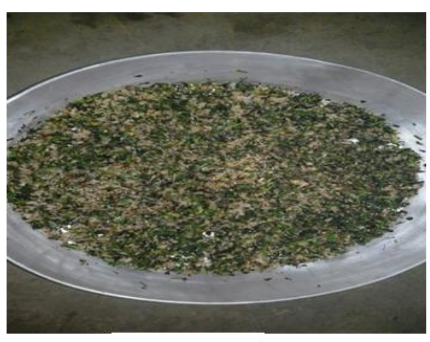

Khazi

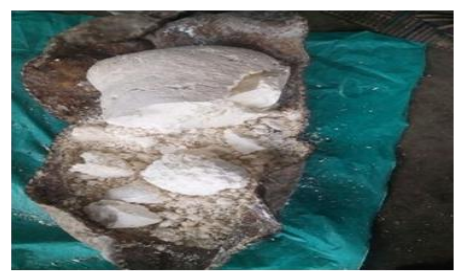

Chhurpi

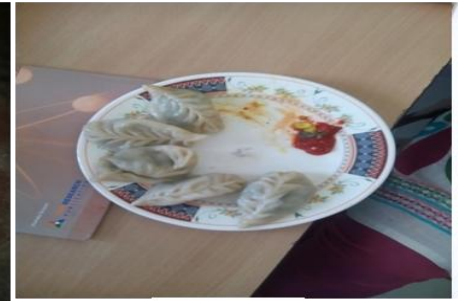

Momo

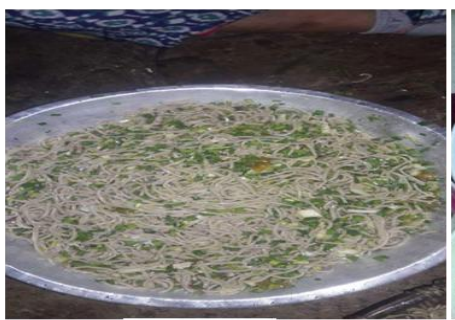

Puta

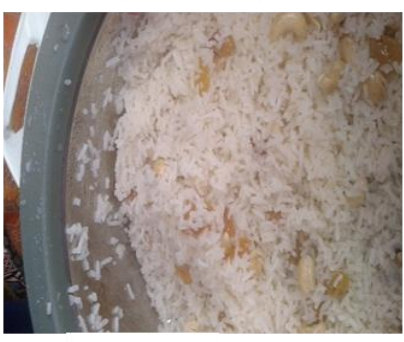

Bresi

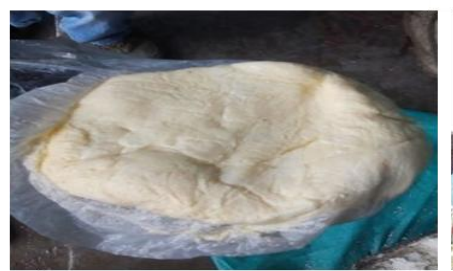

Yak Fat

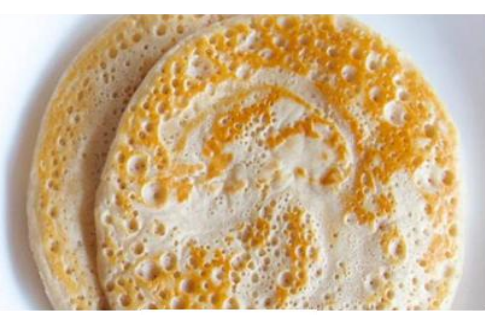

Khura

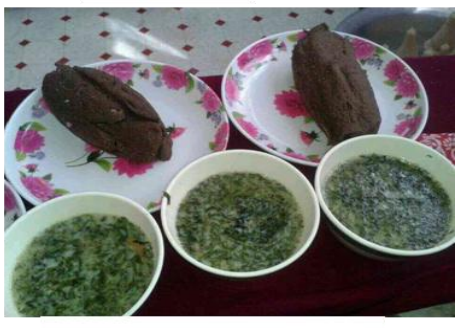

Tsizing Kyola

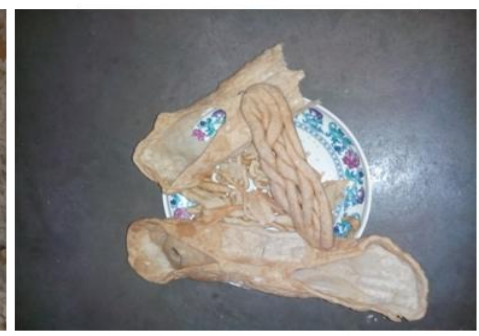

Khapse

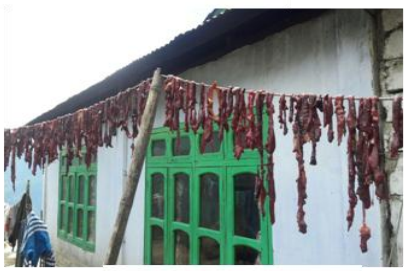

Yak Meat 


\section{Puta}

The Monpa version of noodles is puta. These are noodles made out of buckwheat flour. The making of Puta is quite a time-consuming and cumbersome process. It is made using a special noodle maker called the Putatzirsheng. The dough is put through noodle maker and is then pressed. The Puta is usually eaten with a stew made of vegetables, fermented cheese and chillies.

\section{Tsizingkyola}

The method of preparing this dish is almost the same as that for Zan except only buckwheat flour is used in it. It is best eaten with thin chamin.

\section{Khazi}

This dishs' ingredients are cooked rice mixed with finely chopped maanpatta, a local vegetable (similar to spring onion leaves), chamin and salt.

\section{Gyapa-khazi}

The Monpa version of the pulao. This dish is prepared by mixing rice, fermented cheese, small dried fish, chilli, butter ginger etc.

\section{Bresi}

It is basically sweet rice. This dish is usually served during ceremonial occasion. Cooked rice is transferred to a basin on which melted butter is poured. It is then seasoned with raisins and sugar.

\section{Khapse}

It is important food made by the Monpa society at festival of Losar (New Year). This is prepared with flour (maida). It is made into eight shaped rolls and fried in soyabean oil
(Refined). It can be stored for 15 months in a well aerated bamboos container.

\section{Chhurpi}

In Monpa society it is a popular staple food prepared by Yak milk. They eat this dish during whole year. As per age this is divided in 3 types-Chhurchirpen, chhursingba and chhurрupu. It is paneer like product made by yak milk after fermentation.

\section{Soyabean chhurpi}

It is a popular and common dish in Monpa society. This product is prepared during October- February. For preparation of this dish, local soyabean seeds are boiled and spread on bomboo mat after draining out the water.

\section{Yak meat}

Yak meat is a mostly like by the Monpa societies living in different altitudes at temperate zone. Surplus amount of meat are dried in sun light for use during the off season.

\section{Yak fat}

Yak fat is known as ghee, is mostly used in chhurpi and other different dishes.

A summary of food items prepared by Monpa tribal communities along with its physical form and time/occasion of preparation is give in table 2 for ready reference.

\section{Beverages and other liquid items and their preparation}

The Monpas are also quite fond of alcoholic beverages or Chang, which are prepared in every house. Chang has a great deal of social importance in the Monpa society, especially 
on all social occasions such as births, deaths, house warming or festivals. The key ingredients used for making chang are rice, maize, millets and barley, which are fermented and distilled. The Monpa brew several kind of chang.

\section{Sing-chang}

It is only made during Losar, the Monpa New Year festival. It is a sweet beer like concoction prepared by mixing together millets, buckwheat and barley. It can be both hot and cold depending on the weather and the drinkers' preference.

\section{Baang-chang}

It is usually prepared from rice but it can also be made by combining millets, maize and barley.

\section{Aarak}

Aarak is made by distilling of maize, millets, rice or barley. It is quite strong and is usually served hot in a small cup.

\section{Marchang}

When aarak (local drink) is fried in yak ghee to remove the unpleasant odour, and then Kongpu (finger millets) flour is added to it and mixed properly the dish is known as Marchang.

\section{Monpa tea}

Unlike most other tribes of Arunachal, the Monpas are quite fond of milk and it's by products Sueja or butter tea is hugely popular with these people. The tea is prepared in the usual way with a few exceptions. In place of normal tea leaves, jari or crude tea leaves are used. The tea is prepared by churning milk, raw butter and a little salt in place of sugar in the jan-d hong (a long cylindrical churn made of wood). The rich butter tea is considered to be effective in the cold weather of Tawang.

The knowledge level about traditional food varies among the women of different villages. It was observed that a gap about traditional knowledge among different age group existed. This was due to lack of knowledge among the new generation and low interest to consume traditional foods. At the moment, traditional food practices techniques used by Monpa tribes are rapidly developed because many traditional programme implemented in the district. After study, it was observed that food preparation, its use and food habit was dependent on religion, ecology, festival and cultural ethics. Traditional food preparation and consumption by Monpas has been gained from the time immemorial. It was clear that majority of tribal population had understanding of preparation method and traditional value of ethnic food and beverage. They know cultural, nutritional and social value of ethnic food, and their close relationship to environmental health should be well recognized. These results are in confirmation with the study conducted by Singh et al., during 2007. Traditional food is not only maintaining good health but have also certain curative properties against disease and disorder. Therefore, before this traditional food knowledge lost forever it must be documented properly. Systematic identification, documentation, value addition and refinement of traditional food need to be interconnected with government policies. This would save the indigenous knowledge of the tribe.

\section{Acknowledgement}

I am very thankful to Gaon Burah, Anchal Samit Members (ASM) and community members for sharing their valuable traditional knowledge on ingenious food and beverage. I 
also express my thanks to Programme coordinator, KVK, Tawang Arunachal Pradesh who provided necessary research facilities. I acknowledge the inputs and suggestions received from DR. R K Singh, CSSRI, Karnal.

\section{References}

Bareh, H.M., 2001. Encyclopedia of NorthEast India 1, Arunachal Pradesh, Mittal Publication, Mohan Garden, New Delhi, 2001, Pp-233.

Dev, A., and Norbu, T. 2015. Enchanting Tawang, District Administration, Tawang, Arunachal Pradesh, pp. 51-53

Maiti, S., Chakravarty, P., Gargi, S., Bandyopadhyay, S., Chauhan V.S. 2013. Ethno - veterinary practices for ephemeral fever of Yak: A participatory assessment by the Monpa tribe of Arunachal Pradesh, Indian Journal of
Traditional Knowledge. 12(1): 36-39.

Singh, R.K., and Sureja, A.K. 2005. Community knowledge and conservation of natural resources: Learning from Monpa tribes of Arunachal Pradesh, Proc Nat Conf on Arunachal Pradesh: Trad in Trans, Linking Ecol, Econ and Ethics, NERIST, Nirjuli, Itanagar, Arunachal Pradesh, September 13-16, 2005.

Singh, R.K., Rallen, O., Padung, E. 2013. Elderly adi women of Arunachal Pradesh: "Living Encyclopedias" and cultural refugia in biodiversity conservation of the eastern Himalaya, India, Environmental Management, 52(3): 712-735.

Singh, R.K., Singh, A., Sureja, A.K. 2007. Traditional foods of Monpa tribe of West Kameng, Arunachal Pradesh, Indian Journal of Traditional Knowledge, 6(1): 25-36.

\section{How to cite this article:}

Nitin Kumar Pandey, D.S. Chhonkar, Dhiraj K. Singh and Sonam Tsering Khumu. 2017. Analysis of Indigenous Food Items of Monpa Tribal Community in Tawang District of Arunachal Pradesh, India. Int.J.Curr.Microbiol.App.Sci. 6(9): 633-640. doi: https://doi.org/10.20546/ijcmas.2017.609.078 